\title{
Desafios para a Formação Docente nos Programas de Pós-Graduação em Antropologia
}

\author{
Ari José Sartori ${ }^{1}$ \\ ${ }^{1}$ Universidade Federal da Fronteira Sul, Chapecó, SC, Brasil
}

\section{Resumo}

Pensar o ensino da antropologia tem sido bastante desafiador, porque exige (re)pensar a transmissão dos conhecimentos antropológicos em diferentes contextos. Neste artigo, pretendemos discutir os desafios metodológicos e pedagógicos na formação de antropólogas/as para o exercício da docência no ensino superior. Para tanto, buscaremos dialogar sobre esses desafios, a partir da pesquisa de pós-doutorado realizada com professores/as de Antropologia no Brasil e em Portugal. Também pretendemos encontrar aproximações nas diferentes áreas do conhecimento em que os docentes da disciplina atuam, considerando as estratégias pedagógicas utilizadas, bem como debater sobre a formação para a docência no ensino superior e os desafios enfrentados pelos Programas de Pós-Graduação em Antropologia de ambos os países. Os resultados obtidos sugerem ser consensual a precária formação para a docência nos PPGAS. Já as proposições sobre a forma de resolver esses desafios são muitas, não havendo uma que seja consensual. Essas proposições serão algumas das principais questões que iremos apresentar e discutir neste artigo.

Palavras-chave: Formação nos PPGAS. Ensino de Antropologia. Antropologia e Educação: Brasil/Portugal.

\section{Challenges for Teaching Training in Anthropology Postgraduate Programs}

\begin{abstract}
Thinking about teaching anthropology has been quite challenging, because it requires (re) thinking the transmission of anthropological knowledge in different contexts. In this article, we intend to discuss the methodological and pedagogical challenges in the training of anthropologists for the exercise of teaching. To do so, we will seek to discuss these challenges, based on the post-doctoral research carried out with professors of Anthropology teaching in Brazil and Portugal. We will also seek to find approximations, in the different areas of knowledge in which Anthropology teachers work, considering the pedagogical strategies used, as well as to debate about the formation for the teaching of higher education and the challenges faced, by the Post-Graduation Programs in Anthropology, from both countries. The results obtained suggest that the precarious training for teaching in the PPGAS is consensual. The proposals on how to solve them are many, and none is consensual. These will be some of the main questions that we will present and discuss in this article.
\end{abstract}

Keywords: Anthropologists Training at PPGAS. Teaching Anthropology. Anthropology and Education: Brazil/Portugal. 


\section{Introdução}

"[...] formamos [nos PPGAS] excelentes pesquisadores e péssimos professores!" (Profa. Br Ametista $)^{1}$

"[...] Por que nós que ensinamos, não temos formação para ensinar? (Prof. Pt Rubi)

"[...] eu acho que se eu tivesse tido acesso a uma metodologia já nos primeiros anos, eu teria pulado muitas etapas. Inventei metas, eu inventei, eu inventei.

(Profa. Br Alexandrita)

A

s epígrafes que abrem este artigo foram expressas no contexto da pesquisa realizada com professoras e professores de Antropologia no Brasil e em Portugal e sintetizam as principais questões discutidas neste trabalho.

Pensar o ensino de antropologia, seja ele em contextos interdisciplinares, interculturais e também nos cursos e Programas de Pós-Graduação em Antropologia é uma temática bastante desafiadora, por exigir (re)pensar a transmissão de conhecimentos antropológicos a partir da perspectiva dos próprios professores-antropólogos; ou seja, exige um exercício de estranhamento sobre uma área emblemática de nosso ofício, que é o ensino. Essa preocupação não é um tema exclusivo de reuniões e encontros de antropólogos brasileiros filiados à Associação Brasileira de Antropologia (ABA), mas também das associações de antropólogos europeus e americanos. No Brasil, a preocupação com o ensino se confunde com a própria fundação da ABA, cuja primeira reunião, em $1953^{2}$, incluiu essa questão como uma de suas importantes pautas. Passados mais de 60 anos da criação da associação, o ensino continuou sendo um tema presente e constante de suas reuniões.

No entanto, a despeito do espaço ocupado na $\mathrm{ABA}$, o problema não tem recebido a mesma atenção em comparação à que se tem dedicado à pesquisa e não ocupa um espaço privilegiado nas Ciências Sociais e, em particular, na Antropologia (GUSMÃO, 2016).

Alguns dos trabalhos realizados ao longo das últimas décadas nas Instituições de Ensino Superior (IES) no Brasil (PIMENTA; ANASTASIOU, 2002; MOROSINI, 2005; SCHWARCZ, 2006; SARTORI, 2010) sugerem que esse não é um problema específico

\footnotetext{
Os/as docentes colaboradores/as da pesquisa foram identificados/as pelas abreviaturas "Prof." ou "Profa.", referindose ao gênero do entrevistado/a, respectivamente "Professor" ou "Professora", seguido das abreviaturas "Br" ou "Pt", referindo-se ao país do entrevistado/a, Brasil ou Portugal, respectivamente. Também foram identificados por nomes fictícios, inspirados nas pedras preciosas encontradas pelo mundo. Ressalvo que os nomes fictícios designados para os/as entrevistados/as não fazem nenhuma alusão à preciosidade e ao significado atribuídos às pedras preciosas.

2 A $1^{\text {a }}$ Reunião Brasileira de Antropologia (RBA) foi realizada no Museu Nacional do Rio de Janeiro, em 1953, embora a ABA só tenha sido fundada por ocasião da 2a RBA, em Salvador, em julho de 1955.
} 
desta disciplina, pois se trata de algo estrutural dos Programas de Pós-Graduação (PPGs) no Brasil, os quais, a partir da Reforma Sucupira, proposta depois do golpe de 1964, consolidaram a hegemonia do requisito, de parte dos professores/as do ensino superior, do título de mestre e/ou de doutor(a). Para obter essa titulação, a ênfase é a pesquisa, já que, depois de titulados, exercerão o ofício de professores/as de antropologia, principalmente nas IES privadas, e de professores/as e pesquisadores nas IES públicas. O descompasso entre a formação que recebem nos PPGAS e o ofício que exercerão, seja em IES públicas ou privadas, cria uma lacuna na atuação desses profissionais para a docência, que se reflete, especificamente, em como ensinam os conteúdos antropológicos.

Uma das maneiras possíveis de conhecer o estado da arte do ensino da Antropologia é situá-lo na história, buscando conhecer as influências recebidas, além do contexto que possibilitou o seu surgimento. No caso desta disciplina no Brasil, consideramos que um breve retorno aos fundadores dessa ciência e a influência por eles recebida em sua formação podem ajudar a esclarecer a sua consolidação, afora as polêmicas e disputas suscitadas.

Alguns antropólogos brasileiros, como Sílvio Coelho dos Santos (1997), Mariza Corrêa (2013), Mariza Peirano (1997) e Roberto Cardoso de Oliveira (2000), têm se empenhado em traçar a história da Antropologia no Brasil e sobre ela refletir. Há um consenso entre eles a respeito da influência de antropólogos estrangeiros, quando, em 1932, foi fundada a Universidade de São Paulo (USP) e se abriu a possibilidade de contratar diversos professores/as.

Cardoso de Oliveira (2002) sugere a constituição da Antropologia no Brasil em três períodos, caracterizando-os como "heroico", "carismático" e "institucional ou burocrático". No primeiro dos três, inclui nomes como Curt Nimuendaju e Gilberto Freyre; no segundo, ou o período "carismático", os nomes coincidem com os da segunda geração, sugeridos por Sílvio Coelho dos Santos. No entanto, enquanto Cardoso de Oliveira e Santos não entram nas polêmicas que marcaram, e ainda marcam, de certo modo, a Antropologia no período de transição entre a segunda e a terceira geração, ou, conforme queiramos, entre o período "carismático" e o "institucional", Mariza Corrêa (2013), em sua reconstrução histórica, inclui algumas polêmicas, como a que surgiu entre Darcy Ribeiro e Roberto DaMatta.

Darcy Ribeiro, após retornar do exílio, em 1975, encontrou um panorama antropológico muito diverso do que havia deixado quando foi cassado e exilado em 1964. Nesses 11 anos em que ficou fora do Brasil, foi criada uma nova estrutura institucional nos Programas de Pós-Graduação em Antropologia Social (PPGAS) pelos antropólogos que por aqui ficaram, bastante diferente da pensada por ele. Em seu retorno, posicionou-se criticamente sobre os rumos que a antropologia havia seguido e Roberto DaMatta (seu "filho" teórico) acabou assumindo publicamente a polêmica que se estendia para além deles, pois envolvia explicitamente as diferenças entre duas concepções sobre os rumos da disciplina praticada no Brasil nesse período. As críticas de Ribeiro simbolizavam sua inconformidade com a institucionalização e a profissionalização da Antropologia. Primeiro, pela "carreira acadêmica", que começou a ser exercida pelos antropólogos, considerada por Ribeiro quase uma perversão do "ofício do antropólogo" (CORRÊA, 2013). Segundo, porque indicava a sua inconformidade com seus novos objetos, que 
deixavam de priorizar a defesa dos povos indígenas e passavam a se interessar por temas, em sua opinião, de "irrelevância social", preocupados com as microrrelações sociais, em detrimento de interpretações globais da sociedade com que ele se ocupava. No entanto, esses novos temas "irrelevantes", segundo sua concepção, alteraram profundamente o objeto de estudo da Antropologia no Brasil e, consequentemente, fizeram surgir novas áreas e temas, que foram incluídos nas pesquisas realizadas nos PPGAS (MARTINS; DUARTE, 2010).

No rol dos novos temas de estudo criticados por Darcy Ribeiro, poderíamos incluir o Ensino da Antropologia, com o que ele provavelmente não concordaria, apesar de ele ter influenciado decisivamente na criação dos PPGAS no início dos anos de 1960. Ribeiro, emblematicamente, representava a transição entre o período das grandes sínteses, surgido na década de 1930, e o início da institucionalização da Antropologia no Brasil a partir de meados dos anos de 1960, que iria consolidar os poucos, mas significativos e atuantes, PPGAS criados nesse período.

A despeito das críticas do autor sobre os rumos da Antropologia no Brasil e de sua crítica aos temas "irrelevantes socialmente", várias pesquisas (SANTOS, 1995; GROSSI; RIAL; TASSINARI, 2006; TASSINARI; RIAL, 2002; GROISMAN, 2006; GUSMÃO, 2009; SARTORI, 2010) indicam que nas últimas três décadas houve uma grande demanda, por parte dos cursos de graduação, das mais diferentes áreas pelos referenciais da Antropologia. A inclusão dessa disciplina na maioria dos projetos pedagógicos dos cursos passou a ser requerida por seu potencial teórico, que passa necessariamente pela compreensão do “Outro", considerando seus valores e suas culturas. É nesse cenário que a disciplina se insere e tudo indica que serão solicitadas contribuições, cada vez com maior frequência, de parte de seus praticantes para compreender o que se tornou um dos seus importantes legados: o estudo das sociedades humanas e o respeito pelas diferenças. A inclusão da diversidade e o respeito às diferenças nos currículos de vários cursos de bacharelado e das licenciaturas têm sido saudados como importantes contribuições da Antropologia para a formação dos/as futuros profissionais dessas áreas. De outra parte, populações indígenas de diferentes etnias demandam da sociedade brasileira, particularmente das universidades, formação em áreas diferenciadas do conhecimento, o que comporta outros desafios para os que ensinam nesse contexto de interculturalidade.

A pesquisa que realizei em IES privadas de Curitiba (SARTORI, 2010) indicou que, se os conteúdos antropológicos encontram ressonância nos mais diferentes cursos de graduação, a formação para a docência, particularmente nos PPGAS, tem sido historicamente negligenciada, pois a ênfase, nesses programas, é a pesquisa. Conforme destacamos, essa negligência é estrutural nesses programas, o que tem exigido, particularmente dos professores/as de Antropologia, algumas estratégias para superar as dificuldades disso decorrentes.

A constatação de que a falta de preocupação com o ensino é estrutural nos programas de pós-graduação em geral (PIMENTA; ANASTASIOU, 2002; PIMENTA, 1999;2000; CAMPOS, 2012) e, particularmente, nos Programas de Pós-Graduação em Antropologia, não significa que o ensino da disciplina esteja totalmente negligenciado. Alguns fatos confirmam isso: a Associação Brasileira de Antropologia (ABA), conforme mencionamos anteriormente, já na primeira reunião, em 1953, escolheu como um dos temas "os 
problemas de ensino da antropologia" e as "possibilidades de pesquisa e de exercício da atividade técnico-profissional em instituições oficiais e particulares" (SANTOS, 1997). A partir da década de 1990, segundo Fátima Tavares (2010), o ensino da antropologia no Brasil foi referenciado pelas publicações da ABA e dos poucos/as associados/as que, naquela década e na seguinte, continuaram essa discussão, enfrentando os desafios da expansão do ensino de antropologia nos diferentes níveis e atravessaram

[...] diferentes momentos que se superpuseram no que se refere aos temas de debate. Nas menções às iniciativas da ABA nos anos de 1994 e 1995, os trabalhos de Peter Fry (2006) e Yvonne Maggie (2006) recordam os temas em pauta daquele momento [...]. (TAVARES, 2010, p. 55)

Em síntese, nos últimos 35 anos, a ABA realizou fóruns, encontros, oficinas, seminários, simpósios, mesas-redondas, grupos de trabalho e reuniões sobre o ensino de Antropologia e sobre a formação de antropólogos, a maioria deles a partir do ano 2000 (SARTORI, 2010).

No entanto, esse esforço, segundo Graziele Ramos Schweig (2020), não se reflete em pesquisas sobre "ensino" ou "educação". A autora chegou a essa conclusão após inventariar e analisar as coletâneas publicadas pela ABA e os trabalhos apresentados em seus congressos, bem como a produção de teses e dissertações nos PPGAS nos últimos anos, quando constatou a escassez de pesquisas sobre o tema e, mais escassos ainda, segundo a autora, os trabalhos que utilizam o método etnográfico ${ }^{3}$.

É preciso, contudo, reconhecer que, mesmo com a escassez de pesquisas sobre o ensino e o emprego do método etnográfico, poderíamos dizer que os vários eventos promovidos e apoiados pela ABA constituem, desde a sua origem, um conjunto de reflexões dos próprios antropólogos/as sobre sua prática pedagógica, sobre a formação e sua (re)produção acadêmica e intelectual.

É a partir desse contexto que serão discutidos os resultados da pesquisa realizada com professores/as brasileiros/as e portugueses/as que exercem a docência em IES superiores públicas, os quais, na grande maioria, são também docentes nos PPGAS e em diversos cursos de graduação de suas respectivas instituições, que oferecem disciplinas da área da antropologia em sua matriz curricular.

\section{Contexto da Pesquisa}

Quando em 2010 concluí a pesquisa do doutorado, sobre o Ensino de Antropologia com docentes de IES privadas em cursos de graduação, entre as várias questões discutidas na tese, duas delas se destacaram. A primeira foi a queixa, quase unânime, dos/as professores/as colaboradores/as daquela pesquisa, de que não tiveram formação para o exercício da docência superior nos Programas de Pós-Graduação em Antropologia Social (PPGAS) que haviam frequentado e que não reconheciam que a sua formação para a docência tenha vindo dos Programas de Pós-Graduação (PPG) cursados no Brasil. E a segunda, para responder a essa falta de formação para a docência nos PPGs, os docentes colocaram algumas "estratégias pedagógicas" em movimento, a partir de "modelos"

\footnotetext{
São duas teses que empregam este método: “as teses de Sartori (2010) e Schweig (2015)” ( SCHWEIG, 2020, p. 40).
} 
inspirados em ex-professores (na maioria deles, seus orientadores/as), colegas ou, então, nas tentativas do tipo ensaio e erro, no exercício da docência superior.

Essas duas questões se transformaram nos problemas centrais da tese. No entanto, se, na tese, a resposta à questão das "estratégias pedagógicas" para o exercício da docência consegui dar uma encaminhamento adequado a ela, o mesmo não foi possível fazer com relação ao reconhecimento de que não foi nos PPGAS (mestrados e doutorados) que se formaram para a docência. Assim, foi com a motivação dessa segunda questão que realizei a pesquisa do pós-doutorado para buscar respostas à falta de formação para a docência na pós-graduação. Sabe-se que não é um problema que diga respeito somente ao campo da Antropologia ou das Ciências Humanas, mas ao modelo de PPG que temos no país.

De outra parte, refletir sobre o ensino da Antropologia exige necessariamente que se compreenda como se dá a formação dos/as professores/as do ensino superior nas universidades brasileiras.

Eunice Durham (2003, p. 152) descreve esse processo antes da Reforma Sucupira, realizada no início do Regime Militar de 1964: “[...] o professor universitário começava como assistente ou como auxiliar de ensino e, atuando junto ao catedrático, acabava virando professor".

Vicente Benedito (1995) sistematiza um dos principais aspectos da docência no ensino superior e na formação do professor universitário:

O que identifica um professor? E um professor universitário? No que se refere à formação, os estudos têm mostrado que: [...] o professor universitário aprende a sê-lo mediante um processo de socialização em parte intuitiva, autodidata ou, o que é pior, seguindo a rotina dos 'outros'. Isso se explica, sem dúvida, devido à inexistência de uma formação específica como professor universitário. Nesse processo, jogam um papel mais ou menos importante sua própria experiência como aluno, o modelo de ensino que predomina no sistema universitário e as reações de seus alunos, embora não há que se descartar a capacidade autodidata do professorado. Mas ela é insuficiente. (BENEDITO, 1995 apud PIMENTA, 2000, p. 3)

Suas análises aguçadas explicitam o modelo atualmente predominante na formação dos docentes do ensino superior no Brasil nos cursos de pós-graduação (tanto in stricto quanto in lato sensu). No entanto, a formação dos docentes universitários não é regulamentada como nos outros níveis de ensino (PIMENTA; ANASTASIOU, 2002).

Segundo Gilberto Teixeira (2005), há um grande paradoxo na exigência de qualificação para ser professor(a) no ensino brasileiro. Exige-se licenciatura para professores/as até o ensino médio, mas não a de professores/as universitários, ou seja, em termos didático-metodológicos, temos professores/as nos níveis primários e secundários que são profissionais do ensino e professores/as universitários quase amadores.

Morosini (2005) caracteriza como "solidão pedagógica" esse sentimento de desamparo da grande maioria dos docentes do ensino superior, pela ausência de uma formação voltada para a docência e pela falta de espaço de interlocução e de apoio para compartilhar o ato educativo.

A formação dos antropólogos também não foge à regra, apesar de suas especificidades. Conforme vimos anteriormente, sua formação no Brasil teve diferentes fases e uma longa trajetória, que se consolidou com a criação dos PPGAS no final da década de 1960 e início 
da década de 1970, assentada no tripé formação acadêmica-pesquisa de campo-ensino, com ênfase na pesquisa.

Raras são as instituições que oferecem cursos de formação continuada para docentes de Instituições de Ensino Superior (IES) ${ }^{4}$.

Segundo Vanessa Campos (2012), há um hiato nos PPGs e certa confusão quanto ao uso dos termos "formação" e "preparação" para a docência no ensino superior. Essa confusão, em parte, está na interpretação do enunciado da Lei das Diretrizes Básicas (LDB), Lei n. 9.394/96, que, por um lado, define a docência superior como uma atividade que exige uma formação especializada, que ocorre preferencialmente na pós-graduação em nível de mestrado e/ou doutorado); por outro, a lei fala em "título de notório saber [que] supre a exigência do título acadêmico". Segundo a autora, a palavra "preparar", empregada para designar o modo como tal profissional será formado, carrega certa superficialidade e descompromisso" (CAMPOS, 2012, p. 4). O que se observa nas IES, em geral, continua Campos (2012, p. 5, grifo da autora) é que "[...] a preparação para docência fica a cargo de uma única disciplina (quando ela é oferecida), denominada Metodologia do Ensino Superior ou Didática do Ensino Superior, com carga horária média de 64 horas/aula [...]", e essa carga horária, ainda na avaliação da autora, é irrisória e fica aquém da mínima necessária.

Sabemos, também, que a "falta de preparação" para a docência não é consensual na área da Antropologia, como tem indicado a pesquisa realizada por Guillermo Vega Sanabria (2015) em seis PPGAS. Em sua pesquisa, Sanabria (2015) constatou que nem todos esses programas “[...] incluem disciplinas de cunho metodológico na grade curricular obrigatória $[\ldots]$ ", sugerindo que a "formação" na área se daria por outras disciplinas, e que tais programas seriam influenciados por outros fatores. Segundo Sanabria (2015, p. 618):

A especialização da formação no âmbito das disciplinas optativas e da orientação encontraria seu correlato na singularização das relações sociais através da inserção nos grupos de pesquisa e da interação com um orientador. Seriam precisamente essa especialização da formação e essa singularização das relações o que, em última análise, geraria o valor diferencial da experiência formativa.

Para o autor, a "formação" dos/as antropólogos ocorre, mesmo na ausência de disciplinas específicas para esse fim, como nos PPGAS, que não oferecem disciplinas de método, uma vez que esse "aprendizado" também acontece quando os neófitos interagem com seu/sua orientador e/ou quando realizam a pesquisa de campo.

Não tenho dúvidas de que os PPGAS habilitam e "preparam" os egressos desses programas para a docência, mas não é esse o foco em discussão, e sim a "formação" continuada dos/as docentes do ensino superior. Concordo com Campos (2012, p. 8) quanto à necessidade de "[...] que a docência seja compreendida enquanto profissão, como prática social concreta [...]. Ninguém se forma no vazio. Formar-se supõe troca, experiência, interações sociais, aprendizagens".

\footnotetext{
4 As universidades, por exigência do Ministério da Educação, têm procurado responder a essa ausência de formação dos docentes nos programas de pós-graduação, particularmente pela crescente presença de jovens professores nas universidades com perfil de pesquisador, por meio da institucionalização dos Núcleos de Apoio Pedagógico (NAPs) nas IES.
} 
No caso do ensino da Antropologia, em que pese o esforço da própria ABA, particularmente a partir das últimas gestões, considero que não há empenho dos programas de pós-graduação com o ensino, pelo menos não nos termos dedicados à pesquisa. Também é fácil constatar que esse não é um problema somente dos programas de pósgraduação e/ou dos Programas de Pós-Graduação em Antropologia Social Brasileira, como igualmente indicam os trabalhos das associações americanas e europeias (DRACKLÉ; EDGAR; SCHIPPERS, 2003).

Como meu foco é sobre a "formação" para o ensino da Antropologia no Brasil e em Portugal, procurei responder à questão que ficou em aberto realizando a pesquisa com professores/as de um PPGAS no Brasil e com professores/as de Antropologia de universidades portuguesas.

Em Portugal, de acordo com Graça Índias Cordeiro e Ana Isabel Afonso (2003), o desenvolvimento da antropologia portuguesa pode ser organizado em três distintos períodos. O primeiro vai da formação inicial, na década de 1870/1880, à Segunda Guerra Mundial, influenciada pelos modelos teóricos propostos pelas correntes difusionista e evolucionista. O segundo, nas décadas de 1930 a 1940, originário de "uma etnografia nacionalista com um sabor de folclore", fica muito próximo ao discurso oficial do autoritarismo da época (LEAL, 1998 apud CORDEIRO; AFONSO, 2003). As autoras identificam o período atual da antropologia portuguesa com a chegada de Jorge Dias em Lisboa, em 1956, como docente na Faculdade de Letras e de Antropologia Cultural no Instituto Superior de Estudos Ultramarinos. Avaliam como emblemática a década de 1960, quando a antropologia portuguesa combinou o conhecimento etnográfico de tradições camponesas com uma busca para definir elementos da identidade e do imaginário nacional (LEAL, 1998 apud CORDEIRO; AFONSO, 2003).

A partir da década de 1970 e 1980, os principais Programas de pós-Graduação em Antropologia se concentram em Lisboa. As principais instituições são os Departamentos de Antropologia da Faculdade de Ciências Sociais e Humanas (Nova FCSH) e do Instituto Universitário de Lisboa (ISCTEA), que oferecem programas de doutoramento em antropologia. Soma-se às duas instituições o Programa de Doutoramento em Antropologia da Universidade de Lisboa (DANT.Ulisboa), que, em conjunto com o Instituto de Ciências Sociais (ICS) e o Instituto Superior de Ciências Sociais e Políticas (ISCSP), em colaboração com o Centro de Estudos Comparatistas da Faculdade de Letras (CEC-FLUL), se consolidou, a partir da década de 1980, como referência no ensino da antropologia em Portugal. Portanto, da mesma forma que os PPGAS no Brasil, esses programas e institutos habilitam os egressos de seus programas para a docência.

Nesse sentido, a inclusão de Portugal se deveu principalmente a afinidades acadêmicas e linguísticas, a redes de intercâmbio, bem como ao lugar que ambos os países ocupam nas "tradições antropológicas" mundiais. Entre outras, destaco a língua portuguesa, comum a ambos os países, o que permitiu comparar autores e obras utilizados como referenciais nos cursos de graduação e pós-graduação; o pertencimento dos dois países ao que comumente se designou de "antropologia periférica" (CARDOSO DE OLIVEIRA, 2000), ou, nos termos de Pina Cabral (2004), o fato de ambos os países participarem de uma "quinta tradição" antropológica no contexto da consolidação da antropologia contemporânea; a criação, em 2012, da Associação Internacional de Ciências Sociais e 
Humanas em língua portuguesa (AILCSH), fruto do diálogo entre as áreas, nos países de língua portuguesa, originária do que foram os Congressos Luso-Afro (CONLAB), no âmbito da qual o debate sobre programas de pós-graduação na língua oficial portuguesa vem se consolidando.

Também encontrei algumas peculiaridades quando entrevistei os/as colaboradores/ as da pesquisa dos dois países pesquisados. Uma delas é que os/as professores/as de antropologia são ou foram docentes da disciplina em diferentes cursos de suas instituições; a outra é que metade dos/as entrevistados/as em Portugal é ou foi docente nos PPGs de seu país, particularmente em Lisboa. Uma terceira proximidade da área é que um terço dos/as docentes brasileiros já foi professor(a) visitante em PPGAS de universidades portuguesas (a maioria delas em Lisboa), bem como um pouco menos da metade dos docentes portugueses já foi professor(a) visitante no Brasil, muitos deles no PPGAS pesquisado. Ou seja, os/as entrevistados/as dos dois países também têm afinidades profissionais e pessoais (como observei nas entrevistas realizadas), além de serem professores/as de antropologia nos dois países.

Um dos principais objetivos da pesquisa, nos dois países, foi compreender os desafios enfrentados pelos docentes no Ensino da Antropologia e buscar aproximações entre os dados obtidos nas IES privadas, com os dados de instituições públicas do Brasil, em áreas e cursos análogos em Portugal ${ }^{5}$. Um outro objetivo foi saber se esses professores/as dos PPGAS no Brasil e de Portugal, que também são ou foram docentes das várias disciplinas de antropologias em outros cursos, consideram adequado o modelo de formação que realizam para os egressos dos seus respectivos programas e para os futuros professores/ as de antropologia nas IES.

Devo ressaltar que os depoimentos dos/as colaboradores/as da pesquisa ocorreram num contexto específico, na maioria dos casos, nas entrevistas que realizei. Uma observação que aqui devo fazer é quanto à forma de expressar tais depoimentos. Caso haja inconsistências e lacunas, devo admitir serem de minha total responsabilidade.

\section{Metodologia}

Nesta pesquisa, utilizei o método de "Entrevistas Narrativas", introduzidas por Fritz Schütze (FLICK, 2009), método bastante empregado nos contextos de pesquisas biográficas.

Entrevistei professores/as antropólogos/as ${ }^{6}$ de uma IES pública federal, no Brasil, que ministram e/ou ministraram aulas de Antropologia em diferentes cursos e que são também docentes do PPGAS que habilita mestres e doutores para o exercício da docência

\footnotetext{
5 A pesquisa, no Brasil, foi realizada no período de março até outubro de 2017. A pesquisa com os/as professores/as portugueses foi realizada nos meses de outubro a dezembro de 2017.

6 Este foi mais um dos desafios desta pesquisa, considerando que foi realizada em grupos com "alteridade mínima" (PEIRANO, 1995). Ou seja, os nativos dominam os códigos do pesquisador, que dominam o método e as técnicas empregadas; compartilham das referências e das teorias que permearam a pesquisa, cujas categorias êmicas são as mesmas do pesquisador, isto é, partilham dos mesmos valores, não só sociais, mas também intelectuais. Portanto, exigese um desafio ainda maior: realizar um duplo exercício de estranhamento do objeto, em se tratando de pesquisas em grupos com “alteridade mínima" e que, ao mesmo tempo, compartilham conceitos de experiência próxima e distante (GEERTZ, 1997), que são semelhantes, tanto para o observador, quanto para os observados.
} 
superior. Em Portugal, as entrevistas foram realizadas com professores de Antropologia em diferentes programas de pós-graduação de Lisboa e também com docentes de diferentes regiões do país, professores/as em áreas análogas às pesquisadas no Brasil.

As "entrevista narrativa" foram iniciadas com uma "pergunta geradora de narrativa", isto é, diretamente voltada ao tópico de estudo, no caso, sobre o ensino da antropologia. Iniciei todas as entrevistas com a pergunta: "Como você se tornou professor ou professora? Gostaria que falasse sobre sua trajetória acadêmica e profissional". Como resposta a esta pergunta geradora de narrativa, o/a entrevistado/a trazia várias questões de interesse para a pesquisa. Na sequência, procurei esclarecer algumas questões e/ou apresentar outros aspectos sobre o tema, a partir de um roteiro semiestruturado.

Posso inferir que o método empregado alcançou seus objetivos quando, no final, eu solicitava aos colaboradores/as que fizessem uma avaliação sobre a entrevista. Os depoimentos que se seguem explicitam essas afirmações de professores/as brasileiros/ as e portugueses/as, sobre a entrevista:

Eu acho que foi bem... Essa estratégia de começar perguntando sobre a trajetória pessoal é boa, porque a pessoa vai lembrando, vai soltando. (Profa. Br Aquamarine)

Acho que está muito legal Ari; está bem construído, assim, [...] está muito legal, [...] você sabe sobre a vida da gente [...] Acho que vai ser muito legal. Você vai ter o mapa muito interessante do quadro do Programa. (Profa. Br Esmeralda)

Para mim foi ótimo. Temos pouco tempo na vida para falar sobre nosso trabalho. (Profa. Pt Serafina)

[...] foi ótimo. De fato, fizestes uma coisa muito mais aberta do que eu estava esperando. (Profa. Pt Cristal)

O feedback recebido também sinaliza que o método utilizado os/as impactou de diferentes maneiras. Para alguns(as), as entrevistas serviram para refletirem sobre a docência, mais especificamente sobre seus aspectos pedagógicos e didáticos:

[...] foi interessante [...] sobretudo eu comecei a pensar sobre a história dos meus métodos de ensino [...]. (Prof. Pt Âmbar)

Eu fiquei particularmente interessada [...] E é muito raro aparecer gente com preocupações pedagógicas [...]. (Profa. Pt Opala)

Achei bom, interessante, bem legal a proposta de nos fazer pensar no aspecto didático. (Profa. Br Heliodoro)

Eu achei interessante falar, é terapêutico também [...]. (Prof. Br Citrino)

Achei ótimo falar sobre esse assunto que é tão raro. (Profa. Pt Maísa)

[...] foi bom. Acho que nós devemos fazer mais, pois estamos completamente mandados pela literatura anglo-saxônica e americana sobre esse assunto e sempre nos socorremos dela. Estamos completamente a desvalorizar um patrimônio reflexivo aqui [...]. (Prof. Pt Jaspe)

Para outros, possibilitou reflexões sobre a pertinência desta pesquisa:

[...] acho que o melhor comentário que eu poderia fazer é que o objeto do seu interesse é particularmente pertinente. E é tão mais pertinente, porque é esquecido. E acho que é tão esquecido por ser tão óbvio. É tão óbvio que a gente até esquece. É tão óbvio, está tão à frente do nosso nariz, tão à vista, por isso que a gente não vê. Por isso, é particularmente pertinente. 
E seria muito bom fazer que isso chegue para outra coisa...que eventualmente, um livro, um artigo seu, mas uma coisa coletiva [...]. (Prof. Pt Rubi)

A última parte do comentário acima expressa também um dos resultados desta pesquisa, não previsto no projeto original, que foi o interesse demonstrado por um significativo número de professores/as brasileiros/as e portugueses/as de participar da publicação deste dossiê, com reflexões sobre as experiências de cada um no ensino da Antropologia.

\section{Entrevistas Narrativas}

As 31 entrevistas realizadas no Brasil e em Portugal ${ }^{7}$ versaram sobre as trajetórias acadêmicas e profissionais dos docentes, bem como sobre a docência nos cursos de bacharelado e licenciatura em diferentes áreas do conhecimento. Procurei abordar nas entrevistas algumas questões sobre o ensino nesses cursos e as estratégias pedagógicas desenvolvidas ao longo dos anos de exercício docente. Busquei também saber com o que a disciplina de Antropologia poderia contribuir para os futuros profissionais dessa área, quais propostas consideravam relevantes para os Projetos Pedagógicos desses cursos (PPC). Por fim, tratei dos desafios que os Programas de Pós-Graduação em Antropologia Social (PPGAS) enfrentam na formação/preparação dos/as antropólogos/as para o exercício da docência. Também tratei do papel do "Estágio de Docência"8, no caso brasileiro, na formação dos/as antropólogos(as), de seus limites e possibilidades.

\footnotetext{
Foram realizadas 19 entrevistas no Brasil e 12 em Portugal, com aproximadamente 45 horas de áudio gravado. O tempo das entrevistas individuais no Brasil e em Portugal foi, no mínimo, de uma hora e, no máximo, de 2h30min. As entrevistas no Brasil foram realizadas com docentes de um único PPGAS, entre os dias $1^{\circ}$ de junho e 29 de setembro de 2017, a maioria delas (15 entrevistas) foi no mês de junho. Em Portugal, foram realizadas entrevistas com professores/as de sete Instituições de Ensino Superior (IES). Dessas sete instituições, nove professores/as eram de quatro universidades públicas de Lisboa e três professores/as, docentes em outras universidades públicas de diferentes regiões do país. Realizei a primeira entrevista no dia 25/10/2017 e a última no dia 11/12/2017.

8 O estágio de docência foi instituído pela Fundação da Coordenação de Aperfeiçoamento de Pessoal de Nível Superior (CAPES), juntamente com um de seus programas, o de Demanda Social (DS), por meio do Ofício n. 028/99, de 26 de fevereiro de 1999. Um dos objetivos principais desse programa é "promover a formação de recursos humanos de alto nível ao País, altamente qualificados para a docência em grau superior, a pesquisa e o atendimento da demanda profissional dos setores públicos e privados" (www.capes.gov.br/oqueecapes/apresentação). Para tanto, foi incluída, na cláusula do convênio mantido com as IESs integrantes do Programa de Demanda Social da Capes, a exigência do estágio docente, nos cursos de graduação, para todos os bolsistas desse programa. Encontravam-se anexas ao ofício de criação do estágio de docência na graduação para alunos de pós-graduação quatro diretrizes para a sua implantação: 1) é parte integrante da formação de mestres e doutores; 2) deve ser realizado sem prejuízo do tempo de titulação do bolsista; 3 ) pode ser de 1 (um) semestre para o bolsista do mestrado e de 2 (dois) semestres para o bolsista de doutorado; e 4) deve ser supervisionado pelo orientador do bolsista. Em 18 de maio de 2000, outro ofício (n. 20/002) esclareceu que: a) o estágio de docência não é aplicado para os bolsistas com experiência de docência no terceiro grau, de pelo menos quatro semestres; e b) a sua obrigatoriedade aplica-se a todos, independentemente de existir ou não cursos de graduação na própria instituição (e caso não houvesse cursos de graduação, a instituição deveria associar-se a outras IESs). Segundo Judith Feitosa (2002), a maioria das IES regulamentou o estágio de docência apenas no início de 2000. Em 2002, a Capes, por meio da Portaria n. 52/002, regulamentou o programa de DS quanto aos seus objetivos e aos critérios para concessão de bolsas. Dos 18 artigos dessa portaria, o $17^{\circ}$ regulamenta o estágio de docência e é composto de oito parágrafos, que tratam: da obrigatoriedade, especialmente para o doutorado e, na ausência dele, para o mestrado; da carga horária de 60 horas e das situações em que pode haver remuneração; da duração, de acordo com os níveis e o cômputo de créditos; da exigência da participação do/a professor/a orientador/a e dos casos de dispensa, dentre outros. No entanto, levando-se em consideração que a institucionalização do "estágio de docência" nos programas de pós-graduação é recente, seriam necessárias pesquisas mais amplas e de maior alcance para conhecer a abrangência e a eficácia deste estágio na formação dos professores do ensino superior que o fizeram, para comparar com o dos docentes que não tiveram essa formação específica, caso de todos os professores colaboradores desta pesquisa.
} 
As entrevistas narrativas, na maioria das vezes, traziam à memória dos/as entrevistados/as experiências das salas de aula. Nelas relatavam situações com que se haviam deparado no início do exercício da docência. Nesses relatos, a grande maioria dos/as entrevistados/as caracterizava esse início de docência com expressões do tipo: foi "pedreira" (Profa. Br Alexandrita); "[...] entrei por uma porta e quis sair pela outra" (Profa. Pt Zafira); "foi um grande choque"(Profa. Br Blenda); [...] levei muita bordoada dos estudantes [...] Eu só lembro que eu sofria muito [...] "passava mal" (Prof. Br Jadson).

Em seguida, relatavam alguns dos seus métodos para superar essas dificuldades, no decorrer dos anos de docência. Essas estratégias que desenvolviam eram empregadas por meio de recursos metodológicos que iam "improvisando" ou lembrando dos métodos dos seus ex-professores/as. Geralmente, essas estratégias eram colocadas em movimento nas situações de crise, de conflitos, ou para resolver impasses nas aulas.

Por exemplo, um professor relata que a utilizou em uma turma de psicologia quando, em determinado momento, os(as) discentes se mostraram "hostis" com uma colega professora:
A professora estava muito mal com a turma da psicologia. E aí ela saiu na metade do semestre ... não me lembro exatamente o que aconteceu, mas alguém me chamou para assumir a disciplina ... Aí eu disse: "Vou para a psicologia ... a professora está arrasada lá com alguma coisa que elas estavam fazendo ... então, vou ter que entrar meio pesado nisso. Não vou poder entrar, assim: pessoal tá, tá, tá ... Aí eu tive uma outra ideia [...] Vou fazer o seguinte: 'vou colocar um espelho em sala de aula e vou pedir para que cada estudante se sente na frente do espelho, para se olhar sobre a situação que está vivendo ..., em relação à disciplina ... aí, eles tinham que vir e sentar ... fizeram fila, cada um vinha, se ol hava no espelho. Eu não me lembro de detalhes o que que eu dizia na hora ... "Bom, aí o que você tá vendo, tá se olhando, etc. e tal ... nesse sentido. A ideia era é essa, né: "Tás te vendo nessa situação de conflito, etc. e tal". [Ari: Para eles, da psicologia, pode ter sido interessante a questão de se colocar no lugar do outro?].
Exato, ... Se não fosse na psicologia, não tinha feito (risos, risos...). Se fosse na engenharia (risos, risos ...). mas, como era na psicologia, ... Eu imaginei ... depois eu fiquei explorando a história e tal ... realmente eu consegui, no meio do semestre, ainda consegui que a turma terminasse o semestre sem aqueles conflitos ... E tal ... não foi nada brilhante a disciplina. Mas, enfim, aquela coisa foi apaziguada ... com essas coisas de técnica de ... enfim, de ... de ... de ruptura, uma performance [...]. (Prof. Br Jadson)

Também o relato de outra professora, nesse mesmo curso, mas em outro momento, sugere outros procedimentos para despertar o interesse dos/as discentes para com a disciplina e, particularmente, com os temas discutidos em aula:

Eu falava para eles lerem Margareth Mead ... Eu pensei: "bom, vou trazer alguma coisa mais parecida com a psicologia, com a escola ...". Aí, eles trabalhavam com umas coisas que não tinha nada a ver ... era superetnocêntrica a leitura que eles faziam". Não deu nada certo ... aí, eu pensei: 'Ah, acho que psicólogos gostam - [olha só a minha tese]: Acho que psicólogo gosta, ... dessas dinâmicas, dinâmica de grupos. Então, eu vou bolar umas dinâmicas de grupo. ..., eu dava uma aula sobre o que é identidade, o que é alteridade. Daí, eu punha uma musiquinha. Agora, a gente vai passear pela sala, vamos fazer dois círculos, um gira para um lado e outro gira para outro, a gente vai olhar pro colega, e pensar: 'o que eu me identifico nele e o que eu não me identifico... Como é que eu estou vendo identidade e alteridade? E aí, eu vou também pensar: e isso me repele ou me atrai?' [...] Por que, às vezes, o fato de me identificar, é uma coisa que repele e, em outras, o fato de identificar, atrai. Eu me atraio pelo que me é idêntico ou me atraio pelo que é diferente? Só sei que adoraram (risos) aí eles falavam: "Nossa, professora, 
você conduz as dinâmicas muito bem, professora. Você parece psicóloga (Risos). Parece, que funcionou. Então, assim, esse tipo de... você tentar... tirar da cartola, alguma outra coisa que vai dar certo. Porque, a impressão que dá, é: se eu seguir por esse método, não vai dar certo, e você tem que perceber no seu dia-a-dia, supercorrido, o que você já preparou daquele programa e de que a coisa não está funcionando [...]. (Profa. Br. Esmeralda)

Outro docente descreve o que ocorreu em um curso, com outros recursos pedagógicos, objetivando despertar o interesse dos discentes para a disciplina:

Tem uma passagem interessante na Odontologia, que eu tive um insight: "O que é que vou fazer com pessoal da odontologia, para ver se eles despertam para Antropologia"? Aí, eu peguei uns livros de Odontologia e "xeroquei" as bocas [que estavam] nos livros. Acho que eram 30 alunos. "Xeroquei" 30 bocas diferentes. Eu dei uma boca para cada um... aí, eu disse pra eles assim: "De quem é essa boca?" (risos, risos ..., risos, risos ...) ... e, aí eu iniciei a discussão de identidade, qual a contribuição da antropologia, etc., etc ... então, com essa coisa, eu criei ... eles se interessaram e tal, na Odontologia ... foi a primeira vez que eu fiz alguma coisa, usei um recurso que não era aquela coisa convencional de chegar na aula ... (Prof. Br Jadson)

O relato de um professor, no curso do serviço social, é emblemático para compreender os processos que empreendeu para atrair o interesse das alunas para com a disciplina, a partir de um fato inusitado definido pelo entrevistado como um "acidente de linguagem":

No serviço social, foi uma experiência meio hilária. Uma vez a gente estava lendo o Laraia [Roque Laraia], "O que é cultura". Um texto bem básico. E, por acaso, eu fui me referir ao Laraia como "lacraia". No momento que eu falei aquilo, todo mundo que estava meio que parecendo um zumbi, de repente todo mundo riu. Ai eu falei: "mas o que foi"? E o pessoal, meio que não querendo falar. Aí eu falei: "Não, vocês têm que me falar, pois foi a primeira vez que o que eu falei teve um efeito". E aí eles comentaram que eu havia falado "lacraia" ... E eu perguntei: "Quem era esse tal de lacraia", ... ai as pessoas começaram a falar ... aí eu falei: mas, isso tem tudo a ver, vamos pensar por que é engraçado, ... e aí a gente começou a falar sobre lacraia e ... as pessoas começaram a despertar ..., como se a gente pudesse falar em antropologia sobre algo tão sem cultura como a lacraia". E aí foi uma forma de se pensar, um outro modo de se pensar o que é cultura. ... "O que é cultura do lacraia"? E, a partir de lá, eu descobri que era por aí,... foi um "acidente de linguagem" que levou a uma nova estratégia didática ... Decidi que realmente, nessa altura, era mais interessante trazer um mínimo de texto para que lessem alguma coisa, mas também pensando em recursos visuais como alguma forma de texto. Pequenos filmes, pequenas imagens ... E também trazendo referência da minha própria experiência em campo. (Prof. Br Heliodoro)

Também o depoimento de uma professora portuguesa é instigante, ao descrever como foi intuindo e construindo suas estratégias pedagógicas no decorrer dos anos de docência, em diversos cursos, como ocorreu no curso de mestrado em Geriatria, com o tema da velhice como construção social:

Eu tinha consciência que eles não tinham a menor ideia dos conceitos [...] Então, fui fazendo ... Fui pensar como transformar essas coisas, em coisas simples, né? E, portanto, dar conceitos e dar pequenas definições dos conceitos no PowerPoint e, depois, dar muitos exemplos etnográficos, filmes e pequenas esquetes. Mas, foi tudo intuição. Não foi nada [...], mas foi um grande sucesso. (Profa. Pt Ágata, grifos meus)

Depois de relatarem as mais diferentes estratégias pedagógicas, busquei compreender como tiveram esses insigths, essas intuições, e se tiveram alguma formação para prepará-los

9 O professor é estrangeiro. 
para essas situações. Questionava-os, principalmente, caso tivessem recebido formação nos PPGAS também para o ensino, se isso teria contribuído para uma melhor preparação para o exercício da docência. As respostas a essa questão são diversas, mas o depoimento de uma professora é esclarecedor: "[...] na área de humanas tem muito mais a ideia de que ensinar é despejar o conteúdo [...] acho que faz 30 anos que eu dou aula, né, e eu acho que se eu tivesse tido acesso a uma metodologia já nos primeiros anos ...eu teria pulado muitas etapas. Inventei metas. Eu inventei, eu inventei [...]" (Profa. Br Alexandrita, grifos meus). Perguntei, então: Como você chegou a isso? O que foi que você inventou?

[...] sendo meio etnográfica em sala de aula. No sentido de pensar: 'bom, quem são essas pessoas aqui? Com quem estou me relacionando durante todo este semestre? Com qual diálogo que tem a ver com esse conteúdo, com esses autores, com essa proposta e como construir um diálogo possível e com essas pessoas? Eu acho que partiu um pouco desta premissa, interrogações, dúvidas: como que eu vou tornar viável essa relação durante o semestre e chegar ao final e dizer: Bom algo interessante se produziu aqui? Eu acho que essa é a grande questão [...]. (Profa. Br Alexandrita)

Considero que esse depoimento da professora é muito pertinente, esclarecedor, pois sintetiza o encontro entre antropologia e educação. Ou seja, indica como o método por excelência da antropologia, que é a etnografia, também tem contribuído para o ensino.

Ao mesmo tempo, porém, esse relato indica que a intuição e a capacidade criativa de cada um, de forma espontânea, são o que acaba constituindo o diferenciador para a docência no ensino superior. E é justamente essa a questão aqui focada: como propiciar que essas experiências intuitivas, espontâneas, sejam sistematizadas, testadas, discutidas, para serem socializadas e incluídas na "formação" continuada dos docentes das IES e, assim, poder sair do formato de vir a ser professor de forma espontânea e "aprender fazendo", conforme criticam autores(as) que têm pesquisado, já há algumas décadas, sobre a docência no ensino superior, como Pimenta e Anastasiou (2002) e Campos (2012).

Reconheço que os egressos dos PPGAS têm uma ótima formação para a pesquisa, mas são poucos os preparados para a docência, conforme diz uma professora "[...] formamos [nos PPGAS] excelentes pesquisadores, mas péssimos professores [...]" (Profa. Br Ametista). O que quer dizer que essa excelente formação para a pesquisa não se reflete na formação para a docência. No entanto, a professora Alexandrita, ao intuir que procurou ser "meio etnográfica em sala de aula [...]", sugere ser possível também trabalhar com esse método.

Grossi, Rial e Tassinari (2006) ressaltam a importância de se introduzir os conceitos antropológicos na educação, pois são campos que necessitam dos aportes teóricos da antropologia, mas com a preocupação de que essa demanda não desqualifique o status do antropólogo.

Já há algum tempo, Gusmão (1997) observava a existência de uma tensão entre esses campos do saber. Segundo a autora, seria ela alimentada por ambos os campos, pois, enquanto a educação não tem sido privilegiada pela antropologia, certas abordagens teóricas também não se constituem objeto de análise na educação. A autora credita esse descompasso entre as duas áreas do conhecimento ao fato de se haver construído a concepção de que à antropologia se atribui a condição de ciência e à educação, a condição de prática. Essa tensão coloca ambas numa encruzilhada: 
Os não-antropólogos buscam um olhar antropológico pelo qual se guiarão nos mistérios da pesquisa de campo. Por sua vez, antropologia e antropólogos se vêm em grandes dificuldades, quando são chamados a tratar dessa realidade, cujo nome é educação, seja por não conhecerem, ou, ainda, por deslegitimarem um certo percurso do passado da antropologia. (GUSMÃO, 1997, p. 8)

A autora defende a conveniência de se resgatar esse debate junto à educação, uma vez que nesse campo se utiliza o referencial da antropologia. Para essa reflexão, procura romper com a ideia comum, tanto na educação quanto na antropologia, de que foi na década de 1970 que surgiram as pesquisas educacionais de tipo etnográfico. A autora parte dos relatos de Galli (1993) sugerindo ter havido, já no final do século XIX, uma aproximação entre esses dois campos, quando a antropologia propunha como temas de algumas pesquisas os processos interculturais infantis e os sistemas educativos.

Margareth Mead, já nos anos de 1930, trazia importantes contribuições a partir da publicação de Growing up in New Guinea. Sua obra é referência obrigatória para pensar a interface entre antropologia e educação, principalmente, segundo Dauster ( 2007, p. 19), quando a autora afirma fazer da "[...] educação objeto privilegiado da Antropologia no interior da escola Cultura Personalidade".

Considero que o livro Etnografia da Prática Escolar, de Marli E. André (1995), é emblemático para esse debate. Nele, a autora se apropria particularmente do método etnográfico de uma forma um tanto quanto pragmática, na tentativa de instrumentalização dos educadores, direcionando a abordagem antropológica em três dimensões ${ }^{10}$, para serem utilizadas em suas atividades pedagógicas e nas pesquisas em sala de aula.

Já Cláudia Fonseca (1999) afirma que o método etnográfico é um importante instrumento para a educação, independentemente da série em que atue o professor. Para que seja eficaz, porém, depende da comunicação entre o agente e seu interlocutor (FONSECA, 1999). Salienta ela, ainda, que não se pode trabalhar com o método etnográfico como se fosse uma receita, nem uma garantia, mas como um instrumento da pesquisa em educação no sentido de estreitar essa comunicação respeitando as diferenças e revendo os preconceitos para superá-los (FONSECA, 1999).

No entanto, considero que a Antropologia precisa se abrir para outras áreas do conhecimento, para além do da Educação, como é o caso da História, da Psicologia e, particularmente, da Psicologia da Aprendizagem. Possibilitando, assim, ocorrer um maior diálogo entre essas áreas.

O depoimento da professora Alexandrita, citada anteriormente, por exemplo, além de ressaltar a importância do método etnográfico em sala de aula, destaca a "experiência" dos discentes como importante instrumento para despertar seu interesse pela disciplina. Conforme ela relata, ao ser instigada a descrever como chegou a esse processo de "inventar métodos", comenta:

Aquela coisa meio freiriana, assim, né? Tu vai muito a partir do que eles estão trazendo. Da experiência deles. Então, tu diz: vamos discutir parentesco [...] mas, eu quero discutir

\footnotetext{
10 A primeira é a "abordagem institucional", na qual a autora relaciona aspectos do contexto da prática escolar: formas de organização do trabalho pedagógico, relações e nível de poder, recursos disponíveis ou carência deles, etc. A segunda é a "abordagem pedagógica", envolvendo conteúdos, atividades desenvolvidas e material didático. Ressalta-se que essas observações deverão privilegiar as dinâmicas em sala de aula, a história pessoal de cada indivíduo, etc. A terceira dimensão é a "sócio-político-cultural", envolvendo o contexto sociopolítico e cultural mais amplo, isto é, o momento histórico, as concepções políticas e sociais e os valores presentes na sociedade.
} 
parentesco a partir do que tu estás me trazendo, da tua experiência de parentesco, da tua experiência de família. (Profa. Br Alexandrita, grifos meus)

A fala dessa professora nos instiga a refletir sobre dois importantes aspectos quanto à educação no ensino superior, qual seja: a referência a Paulo Freire e sua intuição de "partir da experiência".

Paulo Freire, conforme já discuti com mais profundidade em outro trabalho (SARTORI, 2010), é considerado um dos mais importantes pedagogos brasileiros e mundialmente respeitado, cujo centenário do seu nascimento foi comemorado neste ano de 2021. No entanto, em que pese sua grande contribuição em favor da educação popular e da alfabetização de adultos, particularmente ao criticar o tipo de educação que chama de "educação bancária" ${ }^{11}$, descontextualizada e conteudista, o autor propõe outra pedagogia - a Pedagogia do Oprimido - na qual a educação surgiria como prática da liberdade.

No entanto, é preciso diferenciar qual o público a que Paulo Freire dedicou suas pesquisas. Existem dois campos específicos que tratam da educação de jovens e adultos: o primeiro envolve o ensino médio da escolarização desse estrato, e o outro é o ensino na graduação.

Marta Kohl de Oliveira (1999) destaca que o tema "educação de pessoas jovens e adultas" (o EJA) não se refere apenas a uma questão de especificidade etária, mas, principalmente, a uma questão de especificidade cultural, pois, apesar do recorte por idade (jovens e adultos são, basicamente, "não crianças"), esse campo da educação não diz respeito a reflexões e ações educativas dirigidas a qualquer jovem ou adulto. Segundo ela, quando se fala do EJA, se está falando de um adulto (e de um jovem) específico, com necessidades específicas de aprendizagem. A EJA, à qual a autora se refere:

[...] não é o estudante universitário, o profissional qualificado que frequenta cursos de formação continuada ou de especialização [...] Ele é geralmente o migrante que chega às grandes metrópoles proveniente de áreas rurais empobrecidas, filho de trabalhadores rurais não qualificados e com baixo nível de instrução escolar (muito frequentemente analfabeto). (OLIVEIRA, 1999, p. 2, grifos meus)

Especificamente para esse adulto da EJA, com pouca ou nenhuma escolarização, existe, de certa forma, uma preocupação metodológica específica e, no Brasil, a maioria das EJAs se baseia na pedagogia de Paulo Freire.

No entanto, a preocupação aqui é com um outro adulto. Trata-se do adulto que está na graduação, o acadêmico do ensino universitário, que exige outros referenciais.

Foi nesse sentido que destaqueio segundo aspecto do relato da professora Alexandrina, quando ela, intuitivamente, reconheceu que procurou "partir da experiência" dos seus alunos/as, acadêmicos universitários.

\footnotetext{
${ }^{11}$ Segundo Paulo Freire, a pedagogia do dominante é fundamentada em uma concepção bancária de educação, em que predominam o discurso e a prática na qual quem é o sujeito da educação é o educador, sendo os educandos como vasilhas a serem enchidas. O educador deposita "comunicados" que estes recebem, memorizam e repetem. Da educação bancária deriva uma prática totalmente verbalista, dirigida para a transmissão e a avaliação de conhecimentos abstratos (FREIRE, 1974).
} 
"Partir da experiência" é um dos referenciais muito importantes da Psicologia da Aprendizagem, especialmente na Teoria da Aprendizagem Significativa (TAS) de Ausubel ${ }^{12}$, Novak e Hanesian (1980), na qual o autor reconhece a importância do conhecimento prévio (das "experiências") como fator decisivo para se chegar ao conhecimento e ao ensino de jovens e adultos ${ }^{13}$.

Considero que a TAS de Ausubel, Novak e Hanesian (1980), por exemplo, poderia ter contribuído para aprimorar a formação para a docência dessa professora já no início da sua carreira, pois, "caso tivesse tido acesso a uma metodologia, já nos primeiros anos [...]", conforme nos relata, realmente poderia ter pulado muitas etapas. Esse depoimento é relevante, pois sugere que poderia ser um dos temas presente na pauta da formação dos futuros docentes nos PPGAS. Entretanto, como não tiveram essa formação para "pular etapas", como diz a professora, foram os insights, as tentativas do tipo ensaio/ erro e, principalmente, os "modelos" (e "antimodelos") de docência encontrados em sua formação - graduação, mestrado e doutorado - que foram inspiradores para muitos.

Chamo de "modelo" toda e qualquer metodologia utilizada pelos(as) docentes, adquirida e inspirada pelos diferentes atores e instituições para dar conta dessa carência em sua formação, em especial quando iniciaram suas atividades docentes. Esses "modelos" podem ser classificados em duas categorias: a) "modelos" recebidos nos PPG (mestrado e doutorado) e/ou inspirados em seus professores/as; e b) "modelos" construídos a partir das experiências fora da academia.

\section{1 "Modelos" Recebidos nos PPGs e/ou Inspirados nos seus Professores/as:}

A maioria, desse grupo pesquisado, creditava aos seus ex-professores/as os "modelos" que a têm inspirado, geralmente recebidos na pós-graduação:

[...] onde, precisamente, era uma maneira bastante original para a época... havia toda essa forma de ensino, o que não era o ensino de cátedra. Era o ensino de seminários, de apresentações dos alunos, expor a biografia que tinha que trabalhar e, portanto, foi aí que aprendi a dar aulas, foi a fazer essas apresentações para os colegas. E, realmente, foi a única formação que eu tive que dar aulas foi nessas apresentaçöes e no que eu vi nos modelos que eu tinha dos meus professores. (Profa. Pt Cristal)

Já os que frequentaram instituições estrangeiras na pós-graduação, particularmente nos Estados Unidos, inspiraram-se naquele "modelo":

[...] Nos Estados Unidos, uma maneira de você sobreviver nas pós-graduação é dar aula como professor assistente. Poucas pessoas receberam bolsa sem obrigações. [...] eu comecei a dar aula e esse foi um grande choque. Era a contrapartida da bolsa. [...] Eu dei aulas grandes, porque já era universidade grande. Eu dei aula para 500 alunos [...]. (Profa. Br Blenda)

\footnotetext{
12 Ausubel desenvolveu, nos anos 1960, a Teoria da Aprendizagem Significativa (TAS), na qual considerou aspectos afetivos no desenvolvimento das capacidades dos adultos para a aprendizagem. Baseado nos processos de cognição, publicou, em 1963, The Psychology of Meaningful Verbal Learning, em que investiga e descreve o processo de cognição segundo uma perspectiva construtivista.

${ }^{13}$ O que é bem instigante, nesse depoimento, foi o fato de que a professora relatou que não conhecia esse autor, sugerindo ter ela agido mais por intuição do que por uma apropriação acadêmica dessa metodologia.
} 
Deixa eu ver... nos Estados Unidos... eu tive uns bons professores, em certo sentido, eu acho que nos Estados Unidos eu senti mais preparo nisso. (Profa. Br. Turmalina)

Já os que cursaram no Brasil reconheceram, por exemplo, que as atividades de extensão das quais participaram e os estágios de docência, para os que tiveram essa experiência nos PPGAS, têm sido lembrados como uma importante experiência para a docência:

O que dá sentido era essa coisa [...] de ensinar antropologia para professores de primeiro e segundo graus. Eu acho que eu peguei aí, porque dai, nesses outros cursos, tinha essas coisas de ensinar para professores. (Profa. Br. Esmeralda)

A minha orientadora. Ela me ensinou muita coisa em termos de didática, de planejamento de aula.... Na verdade, é como se eu tivesse feito umas cinco vezes estágio de docência nessa disciplina. (Prof. Br. Olivin)

[...] Pois é, eu tive bons professores (risos) [...] uns mais didáticos, outros menos, e tal. A própria professora $(X)$ [cita o nome de uma ex-professora, agora colega sua no PPGAS], é uma excelente professora, mas também é no estilo seminário e tal. (Profa. Br Coral)

Além de "modelos" que encontraram em seus ex-professores/as, muitos também serviram de "antimodelo":

Um pouco observando os meus professores, tanto os que eu admirava muito, quantos que eu achava que não tinha uma boa didática. Conseguindo estabelecer o que eu achava que funcionava, vinham para mim. (Profa. Br. Greta)

Ou seja, o que eu aprendi [para a docência]? Pelo que eu li, pelas aulas que eu vi. Se eu gostei ou não gostei do docente. Então, nesse sentido, está claro, isso é que um aprendizado também. (Prof. Br. Lazuli)

Os relatos acima sugerem que o "fazer-se professor/a" foi construído no convívio com os/as ex-professores/as na graduação, no mestrado e no doutorado, a partir das experiências positivas, fossem elas relacionadas diretamente às aulas, mas não somente estas, fossem elas vivenciadas em atividades acadêmicas realizadas em outros espaços, como as atividades de extensão, por exemplo.

\section{2 "Modelos" Construídos a Partir das Experiências Fora da Academia}

Alguns reconheceram que os "modelos" de docência foram apreendidos em diferentes circunstâncias e instituições, todas fora da academia, conforme sugerem diversos relatos:

[...] eu não lembro quando foi que eu aprendi a fazer isso [de dar aulas] [...] Eu acredito, que pode ter sido efeito de um resultado da minha militância política. (Prof. Br Jacinto)

[...] posso dizer que boa parte da minha formação ela veio de fora, veio da militância dos grupos de estudo que a gente formou no sindicato. (Profa. Br Alexandrita)

[...] Dava aula na aliança francesa. Que era um lugar que tinha formação pedagógica para ensino de línguas. E dar aula de línguas é uma coisa muito difícil e sem formação pedagógica, tu não ensina. (Profa. Br Ametista)

[...] essa experiência na ONG, tinha um método particular de ensinar os professores, que todos nós tínhamos que seguir. E eu acabei aprendendo algumas coisas [...]. (Profa. Br Greta) 
Acho que ser músico ajudou. Porque eu, por acaso, nunca tive o pavor de ter uma plateia. Eu sei que muitos dos meus colegas, quando no início, leem os textos é porque têm medo da plateia. Eu não era tanto; era mais insegurança à matéria [...] já toquei para 10 mil pessoas, quando era mais novo [...]. (Prof. Pt Ônix).

Enquanto o primeiro "modelo" está diretamente relacionados às atividades acadêmicas - com o reconhecimento, mesmo com críticas, de que teria sido a partir dessa experiência que se construíram professores/as, o segundo "modelo" ressalta que foi fora da academia, na militância política, nos movimentos sociais, no movimento sindical, na atuação em ONGs, entre outros, que se inspiraram.

Uma das leituras que podemos fazer dos relatos apresentados é de que essa experiência, a de fora da academia, foi a mais inspiradora no "modelo" classificado como "representativo" para a sua formação. Tal leitura leva a defender essa perspectiva, por ficar claro que esse grupo de professores/as credita sua formação para a docência não aos "modelos" encontrados nos seus mestres(as), pois as tiveram também como os demais, mas a uma experiência fora desse campo do conhecimento e ao privilegiarem essa "experiência" em sua narrativa, o que é um indicativo de que a atuação nesses espaços os "formou" mais para a docência. Esse segundo grupo considera que a experiência fora da academia, a que exigia uma dose de exposição pública, por exemplo, ser protagonista em um show de música, ministrar aulas a grupos populares por meio de projetos de extensão e/ou atividades de formação de ONGs, paticipar da formação nos partidos políticos que militavam ou da formação para dirigentes sindicais de trabalhadores(as) sindicalizados foram considerados "modelos" que reconhecem inspiradores para a sua atividade docente até os dias atuais, mais do que as experiências e vivências na academia para prepará-los para a docência.

Há que se destacar que a maioria dos relatos sugere ter sido ao longo dos anos que alguns continuaram empregando esses mesmos recursos, enquanto outros indicam ter desenvolvido seu próprio método.

\section{Sugestões/Proposta para os PPGAS}

A partir desses relatos, que chamo "estratégias pedagógica", "modelos" e "antimodelos", nos quais os entrevistados se inspiraram na formação para a docência, procurei saber dos/as interlocutores(as) quais seriam suas sugestões e/ou propostas para os PPGAS, considerando reconhecerem e admitirem a falta de formação para a docência nesses programas, uma vez que todos/as os/as entrevistados/as, no Brasil, e uma parcela significativa dos/as docentes portugueses, são também professores/as em PPGAS em seus respectivos países.

A constatação é de que é praticamente consensual entre os entrevistados/as, dos dois países, que os PPGAS não formam e não têm como preocupação principal preparar seus egressos para a docência no ensino superior. Essa constatação está bem sintetizada no depoimento de uma professora:

Acho que nosso curso não prepara a gente para isso. [...] é uma lacuna na nossa formação profissional. Realmente, acho que a gente precisa ter uma espécie de disciplina, metodologias 
e formas de abordar porque a única coisa que eu aprendi foi leitura de seminários [...] a gente reproduz em sala de aula, porque acaba virando isso mesmo. (Profa. Br Jade)

Os motivos elencados são diversos e o depoimento a seguir corrobora com os resultados de várias pesquisas realizadas sobre a falta de formação para a docência superior (PIMENTA; ANASTASIOU, 2002; SARTORI, 2010; CAMPOS, 2012):

Eu acho que existe uma presunção na academia, que...que a atividade intelectual, de discutir, de ver criticamente textos, de construir algum quadro teórico ou coisa parecida, é suficiente para dar aula...

[Ari: Sei o assunto, sei ensinar?]

Ah, sim... sei o assunto, sei discutir, demonstra consistência de problematizar; é suficiente para dar aula. Então, nós não temos nenhuma atividade, nem no mestrado, nem doutorado, que seja, exatamente, formadora desse professor, de um professor. Parte-se do princípio de que é implícito na atividade de reflexão e de discussão acadêmica, estar colocada às atividades da .... da docência. [...] É aquela coisa, existe muito no Brasil, essa coisa de que você aprende no ato, né... [...] não existe, do meu ponto de vista, nenhum enfoque no mestrado ou no doutorado para, digamos, a formação de professores. (Prof. Br Jadson)

No entanto, se parece ser consensual "a causa" sobre a falta e/ou a deficiência na formação dos PPGAS para atuarem na docência superior, as propostas para a superação do problema não são consensuais; algumas delas não convergem. Há divergências internamente no PPGAS e, também comparativamente, nas propostas dos dois países. No entanto, considero que essas divergências estão mais relacionados a questões conjunturais do ensino superior, distintamente vividas no Brasil e em Portugal, do que propriamente a divergências epistemológicas para a superação do problema.

Em Portugal, uma das justificativas apresentadas, para não incluir nos PPGAS a questão do ensino, é porque se trata, segundo alguns, de um princípio ético, pelo contexto do campo de trabalho dos/as antropólogos no país. Com relação ao ensino da Antropologia em Portugal, especificamente, não há perspectivas profissionais animadoras em um futuro próximo, nomeadamente quanto à abertura de vagas para docentes de Antropologia nas universidades portuguesas. Portanto, segundo esses depoimentos, a inclusão nos Programas de Pós-Graduação em Antropologia das disciplinas sobre o ensino poderia "passar a ideia" de que há perspectivas profissionais para os egressos dos programas. No contexto atual, seria até mesmo antiético fazer isso:

\begin{abstract}
Aliás, seria um pouco desonesto se nós colocássemos isso em termos de cadeiras, com uma espécie de formalismo do gênero: 'vamos aprender a ensinar'. Percebe? Porque eu não posso dizer aos aluno de antropologia que eles terão lugar na carreira acadêmica. Porque as limitaçôes das carreiras acadêmicas são tantas que a gente sabe que o que muitas pessoas daquelas vão fazer é um pós-doc e depois um segundo pós-doc [risos], enfim. [...] Mas, a questão é que se eu estou a fazer isso para formar sobre todos professores da antropologia, ou não. E o que eu não posso fazer eticamente neste momento é dizer aos meus alunos que parte da formação é para eles mais tarde serem lectores, dentro da antropologia. Porque eu não posso garantir isso. Estás a ver? (Prof. Pt Pedro Lucas)
\end{abstract}

Há também divergência quanto ao lugar da Ciência da Educação na formação dos/as antropólogos/as portugueses. Para alguns, há o receio de incentivar uma certa pedagogização da Antropologia: 
Mas eu acho que precisa ter algum cuidado ... com a história das ciências da educação. Eu acho que ele tem que ter muito bom senso ..., não transformar, a certa altura, o risco que é fazer Ciências da Educação, isto é, transformar o ensino da antropologia em Ciências da Educação. (Profa. Pt Pérola)

Para outro professor, também de um PPGAS, é o contrário:

Outra questão: É que se nós levarmos a sério a existência de uma área chamada educação, ali há uma faculdade de Ciências da Educação e há especialistas da educação e haver ensino sobre ensinar deveria ser feito para essas pessoas. Ou seja, se eu quero levar a sério que aquela área científica existe, então, o que eu devia fazer é contratar alguém para dar essas [...]. (Prof. Pt Pedro Lucas)

Já, no caso do Brasil, "as propostas" apresentadas pelos docentes podem ser sistematizadas em dois grupos: $1^{\circ}$ ) o dos que apostam no "estágio docente" ou em alguma disciplina específica, como importante instrumento para equacionar o problema da falta de formação para a docência; e $2^{\circ}$ ) o dos que projetam essa melhoria por meio da ampliação da carga horária das disciplinas clássicas na formação dos programas de mestrado e doutorado, ou mesmo apostando na manutenção do modelo vigente, expresso no posicionamento de um professor:

[...] eu acho que estão sendo formados melhor para pesquisador do que para professor. Mas eu também não sei se todos concordariam com as medidas que deveriam ser tomadas para acabar com esse problema.

[Ari: Terias alguma ideia?]

Eu tenho. Teoria antropológica um, teoria antropológica dois.... História e teoria antropológica [...] um ano e meio de formação forte sobre história da disciplina. (Prof. Br. Topázio)

Essas duas propostas divergem, tanto no número de apoiadores(as) quanto na maneira de as realizar. Enquanto a segunda, com poucos apoiadores, reforça a ideia de que a solução passa por uma melhor formação dos/as mestres e doutores/as, enfatizando que a resolução do problema está na ampliação da carga horária dos conteúdos antropológicos, a primeira reconhece que, mesmo sendo os conteúdos imprescindíveis para a docência, somente esses não são suficientes.

A grande maioria (em torno de $75 \%$ dos/as entrevistados/as no Brasil) considera que o "Estágio de Docência" (ED) tem potencial, senão de solucionar, pelo menos de melhorar a qualidade da formação para a docência dos/as egressos dos PPGAS. No entanto, essa aposta no "ED" vem sempre acompanhada de críticas na maneira como ele está sendo realizado nos programas.

As sugestões compreendem proposições de atividades com avaliação e acompanhamento que favoreçam a autonomia do aluno, como a proposta do prof. Br Berilo: "Estágio docência com o caráter de um pouco mais de autonomia desses alunos".

Poderíamos incluir também, nesta segunda proposta, uma espécie de "roteirização", de fluxo para a realização do estágio de docência:

[...] uma coisa interessante seria definir do estágio docência algumas etapas minimas que eles teriam que passar [...]. Talvez uma coisa seja roteirizar estágio docência no sentido de pensar: bom, qual o mínimo de experiência eles têm que ter para considerar que fizeram estágio docência? Dar tantas aulas? Preparar alguns exercícios? Podia se roteirizar. Isso é uma possibilidade. A outra é criar uma disciplina. (Profa. Br Alexandrita) 
Ou seja, indicam que os procedimentos e o acompanhamento do "estágio de docência" deveriam ser, de alguma forma, institucionalizados no PPGAS. A questão é como proceder para "roteirizar" e "institucionalizar", considerando que já há acúmulo de experiências individualizadas. Nas entrevistas, vários docentes relataram, com bastante ênfase, como procedem na realização do estágio de docência com seus orientandos/as. Alguns avaliam positivamente suas experiências na orientação desse estágio; outros, nem tanto. Por exemplo, há docentes que exigem dos seus orientandos/as, independentemente de ser bolsistas Capes ou CNPq, que realizem o ED como requisito para ser seu orientado/a: [...] todos vão fazer estágio comigo, os mestrandos e os doutorandos. Não vão sair daqui sem fazer o Estágio Docente, independentemente de ter bolsa ou não (Profa. Br Tanzanita).

Outros consideram que a sua orientação no ED é um "desastre". Ou seja, a forma como é desenvolvido o ED depende mais da ideia que cada docente orientador(a) se faz dele e muito pouco das exigências institucionais.

Quanto à questão de "institucionalização" do ED no PPGAS, esta gera polêmica, particularmente quando se discute se se deveria aplicar por meio de uma disciplina (obrigatória ou optativa) e com créditos:

Eu não sei se na pós-graduação a gente tem que fazer isso. (Profa. Br Morganite)

Talvez a questão seja importante, mas a institucionalização? Eu não acho que se fosse assim, então, o estágio docência era um sucesso. Transformaria todo mundo em professor. (Profa. Br Coral)

[...] seria legal que tivesse uma disciplina, nem que seja de dois créditos: como montar um programa, como montar uma prova, como corrigir uma prova. Pega um programa legal, analisar junto com eles, porque que esse programa é bom. Porque este outro, não é? Pensei na pós-graduação. Existe disciplina? Não! Mas, não é proibido, né? Pode ser dentro ou fora do programa, se for bem concebido, pode servir para qualquer disciplina. (Profa. Br Aquamarine)

Constatei haver uma tendência, por parte de um número significativo dos docentes do PPGAS no Brasil, de que, caso o ED se constituísse em uma disciplina, esta deveria ser optativa e não obrigatória. Os que a propõem são de opinião que é mais adequado considerar o ED uma disciplina optativa. A dúvida é, para alguns, quanto à viabilidade de criar uma disciplina optativa somente para os que têm interesse no ensino. Essa dúvida vem em resposta a certa resistência encontrada por parte dos discentes quando realizam o ED, uma vez que um significativo número deles não considera que o ED seja uma etapa importante de sua formação. Exigir que seja obrigatório poderá criar ainda mais resistências:

[...] tem outras ciladas no campo também em preferências teóricas [...] Por isso, que eu digo: eu acho que seria criar mais problemas ao institucionalizar uma coisa meio obrigatória. Mas, investir mais no Estágio Docência mesmo. Eu gosto muito quando tem alguém interessado. E também é muito ruim você pegar um aluno que tem que fazer Estágio Docência porque ele é obrigado a fazer pela bolsa e não tem o menor interesse no ensino. (Prof. Br Olivin)

Pode-se levar em consideração a tendência, por parte de um número significativo de professores/as, em fortalecer o estágio de docência como uma maneira de "formar" mais e melhor os egressos do PPGAS, inclusive para a docência superior. No entanto, considero que sua efetivação deverá necessariamente submeter essas diferentes perspectivas a um equacionamento coletivo. 


\section{Considerações Finais}

Após finalizar esta pesquisa, posso afirmar que consegui responder, em parte, à principal questão que procurei investigar: como equacionar a falta de formação nos PPGAS para a docência no ensino superior.

Em síntese, as entrevistas realizadas e as análises apresentadas indicam ser consensual que os PPGAS não formam seus egressos para a docência, mas, ao mesmo tempo, se admite tratar-se de um tema que precisa ser discutido nesses programas.

No entanto, pode-se reconhecer que os PPGAS, nos dois países, não têm preocupação com a docência, que a ênfase é a pesquisa, expressa na frase de uma das entrevistadas: "[...] formamos [nos PPGAS] excelentes pesquisadores e péssimos professores!" (Profa. Br Ametista), há que se admitir que ela traz, além das questões indicadas acima, outros desafios que deverão ser considerados.

Por exemplo, caso optem (no PPGAS do Brasil) pela institucionalização do “Estágio de Docência" no formato de uma disciplina, quem estaria animado/a a incluir, além das suas pesquisas, orientações e demandas (que já são grandes, conforme relatam), mais essa tarefa de pensar o ensino na formação de seus egressos? Quem assumirá essa tarefa, independentemente de ser uma optativa ou obrigatória, conforme indicam? Ou uma "obrigativa", conforme sugiro, isto é, obrigatória para os que têm a obrigação de realizar o Estágio Docência (por exemplo, bolsistas da Capes) e optativa, para os demais.

Considero, no entanto, que, independentemente dessa alternativa, o estágio de docência não poderia assumir o formato de uma disciplina qualquer, admitido que a proposição exigirá interlocução entre pares, o que demandará negociação, discussão e, principalmente, colaboração entre todos/as que participam do PPGAS.

Considero haver no Brasil, nesse PPGAS, as melhores condições para a implantação de uma disciplina para o estágio de docência proposto do que em Portugal, pois, mesmo os poucos que têm dúvidas e/ou não o reconhecem como um recurso que poderá melhorar e capacitar os egressos para a docência, em nenhum momento se opõem diretamente a ele. Portanto, há um grande otimismo relativamente ao instituto do Estágio de Docência. Esses docentes do PPGAS poderão ser protagonistas das mudanças que ocorrerão nesse programa e, quiçá, nos programas Brasil afora. Nesse sentido, caso se consiga implantar, certamente se positivará a frase de abertura deste artigo: "[...] Por que nós, que ensinamos, não temos formação para ensinar? (Prof. Pt Rubi).

Também avalio que haverá um maior reconhecimento, por parte dos docentes deste PPGAS no Brasil, da importância que o ensino terá no programa e, possivelmente, com reflexos positivos no "Lattes" de todos, pois acredito que estarão motivados a registrar no seu currículo também as orientações do Estágio de Docência, as quais estavam subnotificadas. Exponho essa questão, pois, a partir do levantamento que realizei no Curriculo Lattes dos/as colaboradores/as da pesquisa no Brasil, somente dois docentes informaram nele que orientaram no "Estágio de Docência" (ED). Essa ausência do registro nos currículos do ED, considero que é muito significativo sobre o lugar que o Ensino ocupa nos PPGs, em geral, e neste PPGAS, em particular.

Enfim, quando iniciei esta pesquisa, tinha sérias dúvidas se conseguiria entrevistar os docentes brasileiros e portugueses para tratar sobre a formação para o ensino superior, 
considerando o lugar que ele ocupa nos PPGAS. Agora, saio dela com grande expectativa de que os(as) docentes deste programa no Brasil poderão ser protagonistas de suas transformações, também para o ensino, uma vez que a docência superior no Brasil é também um dos campos de trabalho promissor, diferentemente da realidade dos/as colegas professores/as portugueses/as. Para estes, as ações para sua atuação dependem da conjuntura política educacional do país, que é bastante restritivo relativamente ao campo de trabalho dos docentes de antropologia, pois, realizar essa mudança não depende somente de seus programas de pós-graduação.

Por fim, mas não menos importante, considero que os resultados desta pesquisa sobre o ensino da Antropologia no Brasil e em Portugal são bastante expressivos. No entanto, estes resultados somente foram possíveis pela colaboração de todos/as os 31 colegas professores/as que generosamente se dispuseram a participar da pesquisa, bem como por suas valiosas contribuições, reflexões e análises que, ao longo das entrevistas, expuseram e compartilharam comigo. Incluo nesse grupo, particularmente, a professora Maria Antónia Pedroso de Lima (Portugal) do ISCTE e as supervisoras desse estágio pós-doutoral, as professoras Antonella Tassinari (no Brasil) e Susana Matos Viegas (em Portugal). Agradeço a elas pelo acolhimento, pela atenção, pelas sugestões, pelos encaminhamentos e indicações de colegas para serem entrevistados/as, as quais foram decisivas para que as entrevistas ocorressem e eu tivesse êxito nos resultados alcançados.

\section{Referências}

ANDRÉ, Marli E. Etnografia da Prática Escolar. Campinas: Papirus, 1995.

AUSUBEL, David Paul; NOVAK, Joseph; HANESIAN, Helen. Psicologia Educacional. 2. ed. Rio de Janeiro: Interamericana, 1980.

CAMPOS, Vanessa T. B. Formar ou preparar para a docência: eis a questão. ANPED, [s.l.], 2012. Disponível em: https://www.anped.org.br/sites/default/files/gt08-2528_int.pdf. Acesso em: $1^{\circ}$ ago. 2021.

CARDOSO DE OLIVEIRA, Roberto. O trabalho do antropólogo. Brasília, DF; São Paulo: Paralelo 15; Editora UNESP, 2000.

CARDOSO DE OLIVEIRA, Roberto. Sobre o Pensamento Antropológico. 2. ed. Rio de Janeiro: Tempo Brasileiro, 2002.

CORDEIRO, Graça Índias; AFONSO, Ana Isabel. Cultural and Social Anthropology in the Portuguese University: Dilemmas of Teaching and Practice. In: DRACKLÉ, Dorle; EDGAR, Lain R.; SCHIPPERS, Thomas K. (ed.). Learning Fields: Educational Histories of European Social Anthropology. Oxford: ASA Berghahan Books, 2003. v. 1. p. 45-67.

CORRÊA, Mariza. Traficantes do excêntrico. In: CORRÊA, Mariza. Traficantes do simbólico \& outros ensaios sobre a história da antropologia. São Paulo: Editora Unicamp, 2013.

DAUSTER, Tania. Antropologia e educação: um saber de fronteira. Rio de Janeiro: Forma\&Ação, 2007.

DRACKLÉ, Dorle; EDGAR, Lain R.; SCHIPPERS, Thomas K. (ed.). Learning Fields: Educational Histories of European Social Anthropology. Oxford: ASA Berghahan Books, 2003.

DURHAM, Eunice. O problema da formação de professoras na Itália. In: GEORGEN, P.; SAVIANI, D. (org.). Formação de Professores: a experiência internacional sob o olhar brasileiro. [S.l.: S.n.], 2003. p. 150-165. 
FEITOSA, Judith P. A. Construindo o estágio de docência da Pós-Graduação em Química. Quim. Nova, [s.l.], v. 25, n. 1, p. 153-158, 2002. Disponível em: https://www.scielo.br/j/qn/a/ dvf4PVXnL43fLn75H7RPGzP/?format=pdfslang=p. Acesso em: $1^{\circ}$ ago. 2021.

FLICK, Uwe. Introdução à Pesquisa Qualitativa. Porto Alegre: ARTMED, 2009.

FONSECA, Cláudia. Quando cada caso NÃO é um caso: pesquisa etnográfica em educação. Revista da ANPED, São Paulo, 1999.

FREIRE, Paulo. Pedagogia do Oprimido. Rio de Janeiro: Paz e Terra, 1974.

GEERTZ, Clifford. O saber Local: novos ensaios em antropologia interpretativa. Petrópolis, RJ: Vozes, 1997.

GROISMAN, Alberto. Ensino de Antropologia em "outros Cursos". In: GROSSI, Miriam Pillar; RIAL, Carmen; TASSINARI, Antonella (org.). Ensino de Antropologia no Brasil: formação, práticas disciplinares e além-fronteiras. Florianópolis: ABA, 2006. p. 333-349.

GROSSI, Miriam Pillar; RIAL, Carmen; TASSINARI, Antonella (org.). Ensino de

Antropologia no Brasil: formação, práticas disciplinares e além-fronteiras. Florianópolis: ABA, 2006.

GUSMÃO, Neusa Maria Mendes de. Antropologia, Cultura e Educação na Formação de Professores. Revista Anthropológicas, [s.l.], v. 25, p. 45-71, 2016.

GUSMÃO, Neusa Maria Mendes de. Antropologia e educação. Interfaces do ensino e da pesquisa. Cadernos Cedes, [s.l.], ano XVIII, n. 43, dezembro de 1997.

GUSMÃO, Neusa Maria Mendes de. Entrelugares: Antropologia e Educação no Brasil. Revista de Educação da Universidade Federal de Santa Maria, Rio Grande do Sul, v. 34, n. 1, p. 29- 46, 2009. Disponível em: https://periodicos.ufsm.br/reveducacao/article/view/1586. Acesso em: $1^{\circ}$ ago. 2021.

MARTINS, Carlos Benedito (coordenador geral); DUARTE, Luiz Fernando Dias (Coordenador de área). O Campo atual da Antropologia no Brasil Horizonte das ciências sociais no Brasil: Antropologia. São Paulo: ANPOCS, 2010.

MOROSINI, Marilia Costa. Professor do ensino superior: identidade, docência e formação. Brasília, DF: INEP, 2005.

OLIVEIRA, Marta Kohl de. Jovens e Adultos como Sujeitos de Conhecimento e Aprendizagem. In: 22a REUNIÃO ANUAL DA ANPED, 26 a 30 de setembro de 1999, Caxambu: ANPED, 1999. Anais [...]. Caxambu, 1999. Mimeo.

PEIRANO, Mariza, G. S. A Favor da Etnografia. Rio de Janeiro: Relume-Dumará, 1995.

PEIRANO, Mariza, G. S. Onde está a antropologia? Revista Mana, Rio de Janeiro, v. 3, n. 2, p. 67-102, 1997.

PIMENTA, Selma Garrida. Relatório do GT Didática. In: 22ª REUNIÃO ANUAL DA ANPED. Caxambu, 2000. Anais [...]. Caxambu, 2000. Mimeo.

PIMENTA, Selma G.; ANASTASIOU, Léa das Graças C. Docência no ensino superior. 3. ed. São Paulo: Cortez, 2002.

PINA CABRAL, J. de. Uma história de sucesso: a antropologia brasileira vista de longe. In: TRAJANO, F. Wilson; RIBEIRO, Gustavo Lins (org.). O Campo da Antropologia no Brasil. Rio de Janeiro: Contracapa; ABA, 2004. p. 249-265.

SANABRIA, Guillermo Vega. A antropologia historicizada ou os índios de Fenimore Cooper: clássicos e história no ensino de antropologia. Mana, Rio de Janeiro, v. 21, n. 3, p. 609-639, dez., 2015. Disponível em: https://www.scielo.br/j/mana/a/h3TV3LXsXtLpBcKxWCKqqGs/?lang=pt. Acesso em: $1^{\circ}$ ago. 2021. 
SANTOS, Sílvio Coelho dos. Sobre a Antropologia hoje: te(i)mas para discussão. In: OLIVEIRA, João Pacheco de (org.). O Ensino da Antropologia no Brasil: Temas para uma discussão. Rio de Janeiro: ABA, 1995.

SANTOS, Sílvio Coelho dos. Notas sobre a construção da antropologia no Brasil. Horizontes Antropológicos, Porto Alegre, PPGAS/UFRG, ano 3, n. 7, 1997.

SARTORI, Ari, J. A experiência como mediadora no ensino da antropologia para quem não vai ser antropólogo. 2010. 400p. Tese (Doutorado) - Programa de Pós-Graduação em Antropologia Social, Universidade Federal de Santa Catarina, Florianópolis, 2010.

SCHWARCZ, Lilia K. M. Ensino de Pós-Graduação: Algumas Primeiras Notas Comparativas. In: GROSSI, Miriam Pillar; RIAL, Carmen; TASSINARI, Antonella (org.). Ensino de Antropologia no Brasil: formação, práticas disciplinares e além-fronteiras. Florianópolis: ABA, 2006. p. 231-248.

SCHWEIG, Graziele Ramos. O ensino da Antropologia. In: BRUNETTA, Antonio Alberto et al. (org.). Dicionário do Ensino de Sociologia. 1. ed. Maceió, AL: Editora Café com Sociologia, 2020. p. 37-41.

TASSINARI, Antonella; RIAL, Carmen. Ensino de Antropologia: Diagnóstico, mudanças e novas inserções no mercado de trabalho. Antropologia em Primeira Mão, Florianópolis, PPGAS-UFSC, Número Especial, 2002.

TAVARES, Fátima et al. Experiências de Ensino e Prática em Antropologia no Brasil. Brasília, DF: Ícone Gráfica e Editora, 2010.

TEIXEIRA, Gilberto. Processo Didático do Ensino Superior. 2005. Disponível em: http:// www.serprofessoruniversitario.pro.br/ler.php?modulo $=7 \&$ texto $=1506$. Acesso em: $1^{\circ}$ ago. 2021.

\section{Ari José Sartori}

Antropólogo, mestre (1999), doutor (2010) e pós-doutor (2018) em Antropologia Social pelo Programa de Pós-Graduação em Antropologia Social da UFSC. Professor Associado da Universidade Federal da Fronteira Sul (UFFS), no Curso de Licenciatura em Ciências Sociais, Campus Chapecó e pesquisador efetivo do Instituto Brasil Plural (INCT). Possui experiência na área de Antropologia, com ênfase em Antropologia Cultural, atuando principalmente nos seguintes temas: teoria antropológica, antropologia da educação, ensino da antropologia, estágios supervisionados, formação de professores, relações de gênero, sexualidade e educação.

Endereço profissional: Universidade Federal Fronteira Sul, Campus Chapecó, SC. CEP: 89802-112.

E-mail: ari.sartori@uffs.edu.br

ORCID: https://orcid.org/0000-0002-7344-3633

\section{Como referenciar este artigo:}

SARTORI, Ari José. Desafios para a Formação Docente nos Programas de Pós-Graduação em Antropologia. Ilha - Revista de Antropologia, Florianópolis, v. 24, n. 1, e81051, p. 135-160, janeiro de 2022. 